\title{
Growth Hormone and Growth Hormone Receptor Genes Expression Related with Productive Traits of Broilers Under the Effectiveness of the Sweet Basil Plant Additive as a Growth Promoter
}

\section{Thair Jawad Kadhim Al-Kelabi ${ }^{{ }^{*}}$, Mayada F. Mohamed ${ }^{2}$, Mohammad Rezaeian ${ }^{3}$, Hassan Al- KARAGOLY ${ }^{4}$}

${ }^{1,2}$ Department of Public Health, College of Veterinary Medicine, University of Baghdad, Iraq; ${ }^{3}$ Department of Animal health and Nutrition, Faculty of Veterinary Medicine, University of Tehran; ${ }^{4}$ Department of internal and treated medicine, College of Veterinary Medicine, University of Al-Qadisiyah, Iraq.

\begin{abstract}
This study aimed to evaluate liver growth hormone (cGH) and growth hormone receptor (GHR) gene expression between broilers fed with sweet basil and control groups. One hundred and twenty day-old broiler (Rose) chicks were raised in ground type housing and lasted 42 days. The broiler chicks were divided randomly into 2 treatment groups of 60 birds, each treatment group was further sub-divide into 2 replicates of 30 birds per replicate (the first group fed basal diet without additive as Control and the second group also fed basal diet with Feed additive $0.5 \%$ sweet basil). The broilers were euthanized by cervical dislocation. RNA was extracted from liver, followed by cDNA synthesis and amplification using RT-PCR. Sweet basil supplementation provided better performance (live body weight gain and feed covariation ratio) results. GHR gene expression in the liver was increased not significantly with sweet basil plant supplementation, but cGH gene expression in the liver was significantly higher in chicks fed sweet basil supplementation than in those fed with control diet. $\mathrm{cGH}$ mRNA levels in broilers fed sweet basil were greater than control (4.03 vs $0.97 \mathrm{AU}$ ). Conclusions: Broilers fed with sweet basil plant, $c G H$ gene expression in the liver where increased significantly $(\mathrm{P} \leq 0.05)$ than in those fed with control diet. Addition of sweet basil plant improved broiler performance by stimulating synthesis and release of growth hormone. Addition SB show increase live body weight gain significantly $(\mathrm{P} \leq 0.05)$ and improved FCR.
\end{abstract}

Keywords | Sweet basil, Chicken growth Hormone gene, Growth hormone receptor gene, Gene expression, Broilers

Received | December 15, 2018; Accepted | January 08, 2019; Published | March 02, 2019

*Correspondence | Thair Jawad Kadhim Al-Kelabi, Department of Public Health, College of Veterinary Medicine, University of Baghdad, Iraq; Email:

alkelabi1981@gmail.com

Citation | Al-Kelabi TJK, Mohamed MF, Rezaeian M, Al-Karagoly H (2019). Growth hormone and growth hormone receptor genes expression related with productive traits of broilers under the effectiveness of the sweet basil plant additive as a growth promoter. Adv. Anim. Vet. Sci. 7(5): 361-369.

DOI | http://dx.doi.org/10.17582/journal.aavs/2019/7.5.361.369

ISSN (Online) | 2307-8316; ISSN (Print) | 2309-3331

Copyright $@ 2019$ Al-Kelabi et al. This is an open access article distributed under the Creative Commons Attribution License, which permits unrestricted use, distribution, and reproduction in any medium, provided the original work is properly cited.

\section{INTRODUCTION}

$\mathrm{T}$ he incidence of contemporary agriculture within the early $21^{\text {th }}$ century guides to terrible genetic election for meat (broiler) and egg (layer) productivity options within the acquainted poultry. To create economical production and rising, the broiler chicken underwent genetic choice specially the striated muscle tissue. In 1950 a broiler needed 112 days previous about to market age while by 1990 birds were visiting market by forty two to forty nine days, nowadays the chicken promoting age below to thirty five days in some lines' production (Parati et al., 2006).

The chicken growth hormone and the growth hormone receptor play a crucial role in chicken performances because of their cardinal functions in growth. To estimate the consequences of choice there's unidirectional diagrammatical by examination the expansion traits and organic phenomenon patterns of recent chicken with inheritance broilers that show growth characteristics the image of those of meat-type birds before to intense choice (Fisher, 2016). 
(Havenstein, 2006) indicated that eighty five to ninety percent of maximizing the alteration in rate noticed through the past fifty years were due to genetic choice, whereas the remaining ten to fifteen percent the noticed improvement during this period back to ameliorated nutritionary ways. Several poultry scientists all over the world are now actively engaged in research into the use of botanicals and plant derived products to fight and reduce the heavy economic losses in poultry industry caused by poultry diseases and used as feed supplements to improve growth performance and the microbial habitat of domestic animals and to manipulate gut functions. (Abbas et al., 2012).

The complete growth and development of chickens are primarily related to the "hypothalamus-pituitary-target organ" pathway (Lin et al., 2012). The neural structure secretes growth internal secretion-releasing hormone and somatostatin. These plays twin roles within the modulation and management of pituitary and internal secretion $(\mathrm{GH})$. GH circulates back to the liver via the blood and bind with the GH receptor (GHR) on the liver cell surface to initiate living thing signal mechanisms that promote the expression of insulin-like growth factors (IGFs). IGFs flow into to the native tissues of the body through the blood and promote cell growth and differentiation (Pierce et al., 2005). Striated muscle is that the major target organ of GH. GH will act directly on the GHRs of striated muscle, producing paracrine and autocrine IGF- 1 to manage muscle growth and development (Lin et al., 2012).

Growth hormone Activity is considerably stricken by its receptors by making the GH-GHR combination (Kühn et al., 2002).

The WHO thought-about that eightieth of the earth's population's trust on ancient drugs for his or her prime aid, needs, and utmost of this medical aid involves the utilization of various plant extracts or their active constituents (Bodeker and Ong, 2005; Jameel et al., 2014). Herbal medicines will function safer alternatives as a growth promoter because of their suitableness and preference, lower value of production, reduced mortality, reduced risk of malady, minimize health hazards and environmental friendliness. Some flavourer product were ready by several medical firms as a poster product that are within the market and desires completely different biological trails to check their claims. Some of the reports have incontestable improvement with relevancy final weight gain, feed potency, down mortality and inflated livability in poultry birds (Ayssiwede et al., 2011; Kumar, 1991). Conjointly such industrial flavourer product preparations have shown helpful effects against diseases because of feed contaminants like aflatoxin, the toxicity caused by chemical medication and fetch further profit per bird.
(Lawrence, 1988) named four major chemotypes of basil: methyl radical chavicol-rich, linalool-rich, methyl radical eugenol-rich, and methyl radical cinnamate-rich. Each methyl radical chavicol and methyl radical eugenol are phenylpropanoids made are examined to be noxious to insects and microbes. Essential oil is thought to possess inhibitor and antimicrobial activity.

The pharmacological action of active plant substances or herbal extracts in humans is well known, but in animal nutrition the number of precise experiments is relatively low (Mohamed et al., 2011), so the aims of this study were to highlight the effect of adding sweet basil as growth promotor on the gene expression of growth hormone $(\mathrm{GH})$ and growth hormone receptor (GHR) genes by using RTPCR and to gauge their impact on productive parameters (live body weight, body weight gain, feed consumption andfeed conversion ratio) of broiler chicken.

\section{MATERIALS AND METHOD}

\section{Experimental Design}

This experiment was carried out in the poultry farm of Veterinary faculty, Tehran University (Amenabad town). The experiment was lasted 42 days start from 15/4/2018 to $26 / 5 / 2018$. One hundred and twenty day-old broilers (Rose) chicks were raised in ground type housing and was divided randomly into 2 treatment groups of 60 bird, each treatment group was further sub-divide into 2 replicates of 30 birds per replicate. All the ethical standards of the faculty of veterinary medicine/Tehran university were conducted in this study (Izmirli et al., 2010). The groups will be as follows (Figure 1):

1.Diet 1-+ basal diet (negative control).

2. Diet 2 - basal diet + added $0.5 \%$ sweet basil.

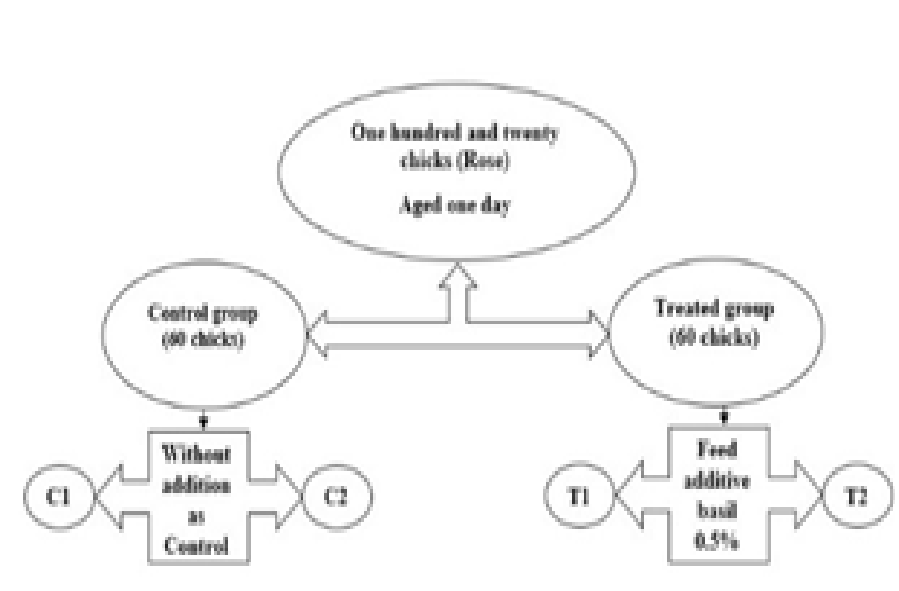

Figure 1: Illustration diagram for the experimental design of the study. 
1. Parameters that were studied in this design: Productive Parameters:

1. Weekly Live body weight.

2. Weekly body weight gain.

3. Weekly feed intake.

4. Mortality percentage.

\section{Growth Hormone Gene (CGH) Expression showing by Real Time PCR.}

3. Growth Hormone Receptor Gene (GHR) Expression showing by Real Time PCR.

\section{Birds Management and Protective Program FOR BroILER DURING THE EXPERIMENT}

Chicks (groups) were reared in $(1.5 \mathrm{~m} \times 4 \mathrm{~m})$ floor pens with a deep litter system of wood shavings. When the chicks reached the farm they were given drinking water with sugar at a concentration of $2 \mathrm{~kg} / 100$ liters. Each pen was equipped with a feeding tray of $38 \mathrm{~cm}$ in a diameter and waterer of 4 liters for three weeks. After that period the trays and cups were replaced by automatic waterer place and feeding trough, the level of the waterer and feeding trough were at the level of bird beaks to help them to get their water and feed easily. Environmental temperature in the first week was $30^{\circ} \mathrm{C}$ and then decreased $2^{\circ} \mathrm{C}$ a week to reach $25^{\circ} \mathrm{C}$ till the end of the experiment. Light was provided for 23-hour light one-hour darkness.

The chicks were vaccinated in boxes by spraying with Newcastle (B1) and infectious Bronchitis (IB) vaccine at the first day of age. After that chicks were given drinking water with sugar $20 \mathrm{gm} / \mathrm{liter}$. The chicks were distributed randomly on their treatments. All vaccines were dissolved in free chlorine water. Waters were holed for three hours before vaccination. Skim milk was added at a rate of $2 \mathrm{~g} /$ liter water. Vitamin $C$ was added at the rate of $1 \mathrm{gm} / \mathrm{lit}-$ er and also vitamins $\mathrm{AD}_{3} \mathrm{E}$ at the ratio of $0.5 \mathrm{ml} /$ liter for 3 days after each vaccination. They received all vaccines, which are listed in Table (1).

Table 1: Protective vaccines program ( $\mathrm{n}=120$ birds).

$\begin{array}{ll}\text { Age } & \text { Vaccines } \text { and the way of vaccination } \\ 1 & \text { Newcastle (B1)+IB is by spray } \\ 9 & \text { Newcastle (LaSota) with drinking water } \\ 15 & \text { Gamboro IBD2 with drinking water } \\ 20 & \text { Newcastle (LaSota) with drinking water } \\ 30 & \text { Newcastle (LaSota) with drinking water }\end{array}$

*All vaccines were obtained fromMerial Company.

\section{Phase Feeding Program}

The feeding program consisted of a starter diet used for the first 14 days of age than grower diet from $15^{\text {th }}$ to $28^{\text {th }}$ day and a finisher diet till 42 days of age. All diets for each period were prepared with the same batch of ingredients, and all diets within a period had the same composition. Diets were formulated to meet or exceed requirements of the National Research Council (1994).

Feed and water were provided in ad-Libitum during the experimental period. The sweet basil powder was added to the basal diet group at a rate $0.5 \%$ for whole period. The composition of the experimental basal diets is shown in Table (2).

Table 2: Composition of experimental diets

\begin{tabular}{llll} 
Ingredient (\%) & Starter & Grower & Finisher \\
\hline Yellow Corn & $\mathbf{1 - 1 4}$ day & $\mathbf{1 5 - 2 8}$ day & $\mathbf{2 8 - 4 2}$ day \\
\hline Soybean meal & 319.8 & 654 & 685 \\
\hline Oil(8900kcal/kg) & 10 & 293.8 & 268.2 \\
\hline Decalcium & 13.6 & 14.4 & 15 \\
Carbonate & 13.4 & 13.4 & 11.2 \\
\hline Salt(NaCl) & 1 & 1 & 1 \\
\hline *Premix & 2.5 & 2.5 & 2.5 \\
\hline *Multivitamins & 2.5 & 2.5 & 2.5 \\
\hline Methionine & 2.8 & 2.9 & 2.1 \\
Lysine & 0.9 & 1.1 & 1 \\
Calculated chemical & & & \\
analysis & & & \\
ME(Kcal/kg) & 2982 & 3027 & 3066 \\
Crude protein (\%) & 20.71 & 19.65 & 18.7 \\
Total & 1410 & 1400 & 1360
\end{tabular}

"Premix: (1\%) provided the following (per kg of complete diets), 1400 IU Vit . A, 3000 IU Vit . D3, 50mg Vit . E, 4gm Vit .K, 3mg Vit. B6, 6mg Vit. B12 , $60 \mathrm{mg}$ niacin , $20 \mathrm{mg}$ pantothenic acid , $0.2 \mathrm{mg}$ folic acid , $150 \mathrm{mg}$ choline , $4.8 \mathrm{mg} \mathrm{Ca}, 3.18 \mathrm{mg}$ $\mathrm{P}, 100 \mathrm{mg} \mathrm{Mn}, 50 \mathrm{mg}$ Fe , 80mg Zn , $10 \mathrm{mg} \mathrm{Cu}, 0.25 \mathrm{mg}$ Co , 1.5 $\mathrm{mg}$ Iodine. Chemical composition according to (NRC 1994).

\section{Productive Parameters}

The chicks were weighed on days $1,7,14,21,28,35$, and 42 per pen. The average live body weights for each treatment were recorded and the average body weight gains were calculated depending on the following equation:

Weight Gain = body weight at the end of the period body weight at the beginning of the previous period.

Feed intake was measured at different period, _ depending on the equation mentioned by (A1-Zubaidie, 1986) and that was done by weighing remained feed at the end of each period and subtracted it from the total quantity offered at the beginning of the period taking in consideration the number of the dead chicks and the number of their feeding days. 
$\mathbf{A}=$ quantity of feed in take for the whole (g).

$\mathbf{H}=$ number of the live chicks fed through the period.

$\mathbf{S}=$ number of dead chicks $\times$ number of their feeding days.

Feed conversion ratio for each treatment was measured using the equation mentioned by (Al-Zubaidie, 1986).

\section{Genetic Parameters}

Birds: White Rose chickens, were used under the same conditions to 7 weeks of age. Randomly selected forty animals from each group were euthanized by cervical dislocation by the end of trial. Liver were collected and stored in RNA Holder at $-20^{\circ} \mathrm{C}$ for posterior RNA extraction.

Extraction of Total RNA: Total RNA was isolated from $2 \mathrm{gm}$ of liver tissues according to the manufacturer's instructions using a SinaPure RNA Kit. All mRNA was quantified by spectrophotometry (ND-2000, Nano Drop Inc., USA). The purity and yield of RNA were determined using optical density at 260 and $280 \mathrm{~nm}$. RNA integrity was examined by electrophoresis on a $1.2 \%$ denaturing formaldehyde gel. These samples of first-stand cDNA were used as templates for amplification of different genes using real-time polymerase chain reaction (RT-PCR).

\section{RNA Isolation AND cDNA Synthesis (SinApure RNA)}

Tissue: A 25-50 mg piece was cut from a fresh tissue (for RNA active tissue $10 \mathrm{mg}$ ). Grinded by a mortar and pestle in liquid nitrogen. Then the powder tissue was transferred to round- bottomed $2 \mathrm{ml}$ tube contains $400 \mu \mathrm{l}$ lysis solution immediately. After that, mixed thoroughly by votexing for one minute. For homogenization the lysate was passed through 20-Gauge needle at least for ten times.For longterm storage, the samples were stored in needed portions and kept at $-20^{\circ} \mathrm{C}$ or colder $-70{ }^{\circ} \mathrm{C}$.

\section{Protocol of RNA extraction:}

Approximate time for total RNA purification is about 15 min.A $300 \mu 1$ precipitation solution was added to a clean $2 \mathrm{ml}$ tube, and invert it for ten times. Then the solution was transferred to spin column with collection tube (included) by pipetting centrifuge the tube at $(12000 \mathrm{x}$ g. 13000RPM) for $1 \mathrm{~min}$. After that, discard flow-through. Then, a $400 \mu$ of wash buffer 1 was added to spin column. Next, Centrifuge the tube at (12000x g. 13000RPM) for 1 min. afterward, discard flow-through.At that time, wash the spin column with $400 \mu$ of wash buffer 11 Centrifuge the tube at (12000x g. 13000RPM) for $1 \mathrm{~min}$. Then, discard flow-through, as well as Wash the spin column with $400 \mu \mathrm{l}$ of wash buffer 11 Centrifuge the tube at $(12000 \mathrm{x}$ g. 13000RPM) for $1 \mathrm{~min}$. after that, discard flow-through, and centrifuge at $12000 \mathrm{~g}$ (13000RPM) for $2 \mathrm{~min}$. Then column was carefully transfer the column to a new $2 \mathrm{ml}$ tube. Placed a $50 \mu 155^{\circ} \mathrm{C}$ pre heated RNase free water in the center of column, and the lid was closed and incubated for $3-5 \mathrm{~min}$ at $55^{\circ} \mathrm{C}$. Thereafter, centrifuged at $12000 \mathrm{~g}$ (13000 RPM) for 1 min to elute the RNA.

Protocol of the $c$ DNA synthesis: After thawing, the components of the kit was mixed and briefly centrifuged, then stored on ice. After that, the RNA-primer mixture was prepared as: template (total RNA) $2 \mu \mathrm{g}$, random Hexamers primer $1 \mu \mathrm{l}$ and DEPC-treated water up to $10 \mu \mathrm{l}$. after that, the mixture was incubated at $65^{\circ} \mathrm{C}$ for 5 minutes and chilled on ice for 2 minutes. Then, the mixture was briefly spin down, and the cDNA synthesis mix was prepared as the following: 10x Buffer M-MuLV $2 \mu \mathrm{l}$, M-MuLV Reverse Transcriptase $0.5 \mu \mathrm{l}$, RNase Inhibitor $0.5 \mu \mathrm{l}(20 \mathrm{u}), 10$ Mm d NTP Mix $2 \mu 1$ and DEPC-treated water top up to $10 \mu \mathrm{l}$. A $10 \mu \mathrm{l}$ of the c DNA Synthesis mix was added into each RNA-primer mixture. Then, incubated at $42{ }^{\circ} \mathrm{C}$ for $60 \mathrm{~min}$. after that the reaction was terminated by incubate the tubes at $85^{\circ} \mathrm{C}$ for $5 \mathrm{~min}$. next, the tubes were chilled on ice and the solution was collected by centrifuge the tube briefly. The synthesized c DNA was directly used in PCR, by addition of $4 \mu \mathrm{l}$ of the $\mathrm{c}$ DNA reaction mixture to a 25 $\mu \mathrm{l}$ PCR reaction.

\section{Expression of growth hormone genes by real time PCR:} The amplifications of growth genes were carried out using an Qiagen`s Real-time PCR machine (Rotor-Gen Q 6000) in $25 \mu$ volume containing 1X QuantiTect ${ }^{\circledR}$ SYBR $^{\circledR}$ Green PCR Master Mix (SYBR ${ }^{\circledR}$ Green 1 dye, HotStartTaq DNA polymerase, and dNTPs in optimized buffer components; Qiagen GmbH, Hilden, Germany), a $0.2 \mu \mathrm{M}$ concentration of each gene-specific primer (Table 3 ), and $4 \mu 1$ of cDNA template. PCR cycling conditions included initial denaturation at $95^{\circ} \mathrm{C}$ for $10 \mathrm{~min}$, followed by 40 cycles of denaturation at $95^{\circ}$ for $30 \mathrm{~s}$, annealing $55^{\circ}$ for $30 \mathrm{~s}$, and extension at $72^{\circ}$ for $45 \mathrm{~s}$. The melt curve was ramped from $72-95^{\circ}$ and rising by $1^{\circ}$. For each gene of interest, negative and positive controls were also included. Negative controls were samples in which cDNA was not added. A melting curve was performed for each sample after completion of amplification and analyzed in comparison to negative and positive controls to determine the specificity of PCR reaction.

The relative expression ratio (ER) of a target gene is computed, based on its real-time PCR efficiencies (E) or a static efficiency of 2 , and the cycle threshold $(C t)$ difference $(\Delta)$ of mean control versus each unknown sample $(\Delta C t-$ control - treatment) as described below (Pfaff, 2001) using the $\beta$-actin as the reference housekeeping gene:

$\mathrm{ER}=(\mathrm{E}$ target $) \Delta C$ ttarget (control - treatment $)(\mathrm{E}$ ref $)$ $\Delta C$ tref (control-treatment). 
Table 3: The primers that used cGH and GHR gene expression.

\begin{tabular}{|c|c|c|c|c|c|}
\hline Accession No. & $\operatorname{Tm}\left({ }^{\circ} \mathrm{C}\right)$ & Size (bp) & Primer sequence & Primer name & Primer purpose \\
\hline \multirow[t]{2}{*}{ NM001001293.1 } & \multirow[t]{2}{*}{60} & \multirow[t]{2}{*}{145} & AACACAGATACCCAACAGCC & GHR-F & \multirow{2}{*}{ Expression profile } \\
\hline & & & AGAAGTCAGTGTTTGTCAGGG & GHR-R & \\
\hline \multirow[t]{2}{*}{ HE608816 } & \multirow[t]{2}{*}{58} & \multirow[t]{2}{*}{201} & CACCACAGCTAGAGACCCACATC & cGH-F & \multirow[t]{2}{*}{ Expression profile } \\
\hline & & & CCCACCGGCTCAAACTGC & cGH-R & \\
\hline \multirow[t]{2}{*}{ L08165 } & \multirow[t]{2}{*}{60} & \multirow[t]{2}{*}{136} & ACCCCAAAGCCAACAGA & $\beta$-actin-F & \multirow[t]{2}{*}{ Internal control } \\
\hline & & & CCAGAGTCCATCACAATACC & $\beta$-actin-R & \\
\hline
\end{tabular}

Table 4: The Folds of gene expression of cGH and GHR genes of livers of broiler chicken. The data expressed as $(\mathrm{Mean} \pm \mathrm{SE})$ and the t-test value also presented in the table.

$\begin{array}{llllll}\text { Gene } & \text { Fold Mean } \pm \text { SE } & \boldsymbol{t} \text {-test } & \boldsymbol{P} \text {-value } & \begin{array}{l}\text { Fold Limits } \\ \text { Lowe }\end{array} & \text { Upper } \\ \mathrm{C}(\mathrm{cGH}) & 0.97 \pm 0.19 & 5.17 & 0.0008_{\mathrm{ab}} & 0.58 & 1.35 \\ \mathrm{~T}(\mathrm{cGH}) & 4.03 \pm 0.20 & 6.64 & & 2.78 & 5.27 \\ \mathrm{C}(\mathrm{GHR}) & 1.11 \pm 0.61 & 5.50 & 0.579 & 0.69 & 1.52 \\ \mathrm{~T}(\mathrm{GHR}) & 2.33 \pm 037 & 6.30 & & 1.57 & 3.09\end{array}$

- C=Control, $\mathrm{T}=$ Treated.

- The small letter (a) represent the significant difference between the same gene of control and treated groups.

- The small letter (b) represent the significant difference between the different two genes.

\section{Statistical Analysis}

Growth hormone and growth hormone receptor gene expression levels were analyzed by t-test using the SPSS software package (Version 22) and the values of gene expression folds were shown as a mean \pm SE. The Difference in mean values was considered as significant at the level of $95 \%(\mathrm{P}<0.05)$ and $99 \%(\mathrm{P}<0.01)$. The $\mathrm{f}$-test and percentage ratio were also used in this study.

\section{RESULT AND DISCUSSION}

\section{GH AND GHR GeNES EXPRESSION}

Melting curves showed no presence of nonspecific product (more than one peak), no primer dimers (nonspecific atomic number 69 peak), thus, indicating the dependableness of RNA transcript identification revealing GHR and cGH-specific primers equal to RT-PCR. Work $\beta$-actin showed nice potency as endogenous management showing no applied mathematics distinction among treatment cluster and management. Quality interval ninety-five reveals that organic phenomenon profile of liver showed differences between treatment and management teams $\left(\mathrm{Ta}^{-}\right.$ ble 4). However, $\mathrm{cGH}$ genes expression within the liver showed considerably $(\mathrm{P}<0.05)$ increase in treated group more than control group.

The discharge of GH in fowls includes three peptidergic discharging factors: development hormone-discharging factor (GRF) (stimulatory); thyrotropin-discharging hormone (TRH) (stimulatory); and somatostatin (SRF) (inhibitory). Besides, the impacts of biogenic amines (counting serotonin and norepinephrine) and prostaglandins at the dimension of the nerve center and perhaps at the same time the pituitary organ has been contemplated. The plasma convergences of $\mathrm{GH}$ are high in youthful post hatching chicks however low in the grown-up and embryo. The more prominent $\mathrm{GH}$ emission and decreased leeway assume a job in the distinction of plasma groupings of $\mathrm{GH}$ among youthful and grown-up birds. The lower emission of GH in adult birds creatures reflects less somatotrophs in the pituitary, changes in somatotroph structure, and lessened $\mathrm{GH}$ reactions to $\mathrm{TRH}$ or GRF administration (Abraham et al., 2005).

Table 5: Effect of sweet basil powder on live body weight gain (g) of Two groups during while period (Mean \pm standard error). ( $n=120)$.

\begin{tabular}{|llllll} 
Weeks & Groups & N & Mean \pm SE & F & Sig. \\
1th W & C.G No & 60 & $89.18 \pm 1.38$ & 41.455 & 0.000 \\
& T.G No & 60 & $100.9 \pm 1.19$ & & \\
2th W & C.G No & 60 & $197.1 \pm 4.11$ & 45.195 & 0.000 \\
& T.G No & 60 & $232.65 \pm 3.33$ & & \\
3th W & C.G No & 60 & $316.08 \pm 6.01$ & 41.643 & 0.000 \\
& T.G No & 60 & $371.45 \pm 6.13$ & & \\
4th W & C.G No & 60 & $450.48 \pm 6.88$ & 69.947 & 0.000 \\
& T.G No & 60 & $527.4 \pm 6.1$ & & \\
5th W & C.G No & 60 & $628.2 \pm 8.92$ & 1.238 & 0.269 \\
& T.G No & 60 & $645.85 \pm 13.12$ & & \\
6th W & C.G No & 60 & $733.98 \pm 15.75$ & 1.782 & 0.186 \\
& T.G No & 60 & $761.93 \pm 13.8$ & & \\
\hline
\end{tabular}

Different (F, Sig) values in columns show significant differences at level $(\mathrm{P}<0.05)$. 
Table 6: Effect of sweet basil powder on live body weight (g) during whole periods (Mean \pm standard error). ( $\mathrm{n}=120$ ).

\begin{tabular}{|c|c|c|c|c|c|c|}
\hline Period & Group & $\mathbf{N}$ & Mean & SD & SE & Sig. \\
\hline \multirow[t]{2}{*}{1 st w } & C.G & 60 & 127.43 & 15.17 & 1.96 & \multirow[t]{2}{*}{0.000} \\
\hline & T.G & 60 & 137.83 & 14.71 & 1.90 & \\
\hline \multirow[t]{2}{*}{$2 \mathrm{nd} \mathrm{w}$} & C.G & 60 & 324.32 & 49.75 & 6.42 & \multirow[t]{2}{*}{0.000} \\
\hline & T.G & 60 & 368.80 & 40.49 & 5.23 & \\
\hline \multirow[t]{2}{*}{$3 \mathrm{rd} \mathrm{w}$} & C.G & 60 & 641.88 & 92.98 & 12.00 & \multirow[t]{2}{*}{0.000} \\
\hline & T.G & 60 & 739.27 & 84.83 & 10.95 & \\
\hline \multirow[t]{2}{*}{ 4th w } & C.G & 60 & 1094.85 & 146.42 & 18.90 & \multirow[t]{2}{*}{0.000} \\
\hline & T.G & 60 & 1270.27 & 125.33 & 16.18 & \\
\hline \multirow[t]{2}{*}{5 th w } & C.G & 60 & 1706.50 & 227.97 & 29.43 & \multirow[t]{2}{*}{0.001} \\
\hline & T.G & 60 & 1887.05 & 323.32 & 41.74 & \\
\hline \multirow[t]{2}{*}{ 6thw } & C.G & 60 & 2439.57 & 304.25 & 39.28 & \multirow[t]{2}{*}{0.015} \\
\hline & T.G & 60 & 2615.05 & 458.08 & 59.14 & \\
\hline
\end{tabular}

Different letters in columns show significant differences at level $(\mathrm{P}<0.05)$.

Table 7: Effect of sweet basil powder on weekly feed consumption (\%) ( $\mathrm{g} / \mathrm{bird})$ during whole periods. $(\mathrm{n}=120)$.

\begin{tabular}{lll} 
& Feed in take(gr)/ Bird \\
Weeks & T.G & C.G \\
\hline $1^{\text {st }} \mathrm{w}$ & 169.1 & 178.0 \\
$2^{\text {nd }} \mathrm{w}$ & 282.2 & 313.6 \\
$3^{\text {rd }} \mathrm{w}$ & 543.3 & 509.2 \\
$4^{\text {th }} \mathrm{w}$ & 847.2 & 802.6 \\
$5^{\text {th }} \mathrm{w}$ & 1088.3 & 1108.7 \\
$6^{\text {th }} \mathrm{W}$ & 1433.8 & 1439.1 \\
Mean & 727.3 & 725.2 \\
$\mathrm{SD}$ & 485.4 & 487.3 \\
$\mathrm{SE}$ & 198.2 & 198.9 \\
$\mathrm{Sig}$ & 0.994 & \\
\hline
\end{tabular}

Table 8: Effect of different levels of sweet basil powder on weekly feed conversion ratio (g/body wt. /feed intake) during while periods. $(n=120)$.

\begin{tabular}{lcc} 
& Feed Conversion ratio \\
Weeks & CG\% & TG\% \\
$1^{\text {st }} \mathrm{w}$ & 1.990 & 1.709 \\
$2^{\text {nd }} \mathrm{w}$ & 1.595 & 1.220 \\
$3^{\text {rd }} \mathrm{w}$ & 1.610 & 1.466 \\
$4^{\text {th }} \mathrm{w}$ & 1.786 & 1.613 \\
$5^{\text {th }} \mathrm{w}$ & 1.766 & 1.695 \\
$6^{\text {th }} \mathrm{w}$ & 1.953 & 1.879 \\
$\mathrm{Mean}$ & 1.783 & 1.597 \\
$\mathrm{SD}$ & 0.166 & 0.229 \\
$\mathrm{SE}$ & 0.068 & 0.093 \\
$\mathrm{sig}$ & 0.137 & \\
\hline
\end{tabular}

\section{Body Weight Gain}

Body weight increase because of the impact of sweet basil as feed added substances is exhibited in Table (5). Amid the primary fourth weeks (1-4 month old) indicated very noteworthy $(\mathrm{P}<0.05)$ increment in body weight gain for treated gathering contrasted and control, yet treatment bunches demonstrated no critical contrasts in fifth and 6th weeks. This might be because of the way that the measure of the feed admission is increment and this lead to that outcomes in the meantime the aftereffect of live body weight that displayed in (Table 5) indicated fundamentally $(\mathrm{P}<0.05)$ increment at all the period and furthermore this is concurrence with the consequence of quality articulation that appearing in the (Table 4). Additionally concurrence with result that do by (Zhao et al., 2004) they are find as a rule, plasma $\mathrm{GH}$ fixation topped at day 21 in the layer pursued by a decay at day 42 , the pinnacle recurrence was declining with age in the two strains of chicken, in spite of the fact that this inclination was seen all the more unmistakably in broilers.

\section{Live Body WeIGHT}

During the whole period (1-6 weeks old) the results of treated group recorded the highest significant $(\mathrm{P}<0.05)$ increase in live body weight as compared with control groups (Table 6). A similar pattern was appeared by Rabia (2010). This noteworthy increment might be because of the way that basil oils offering the best advantages frequently contain abnormal amounts of methyl chavicol, eugenol, linalool, camphor, and methylcinnamate (A1-Kelabi and Al-Kassie, 2013).

Numerous specialists demonstrated that impact of cinnamate and its subsidiary mixes has an impact in assimilation and feed digestion, since this compound has a functioning job in upgrading the digestive tract motility and the aggregate emission of bile through it's animating job for enzymatic stomach related channels discharges and furthermore for the digestive system and pancreatic discharge (Alp et al., 2012).

The referenced examinations in the writing audit demonstrated the principle constituents of sweet basil incorporate chavicol methyl ether or estragole, linalool and eugenol, and that did by (Özcan and Chalchat, 2002) whom recommended that linalool is the most dynamic specialist in charge of antibacterial movement, which caused an expansion in grills body weight additions and linalool thought about the antimicrobial dynamic among most sweet basil segments and caused sanitization of the gastrointestinal tract, because of enhancing feed usage and causing an expansion in every day body weight gains.

These findings agreement with (Nweze and Ekwe, 2012) was highlighted that broilers fed dietary supplement of 
(Ocimum gratissimum that belong to the same Family: Lamiacaea) extract had higher final body weight and weight gain.

In any case, different specialists found that these enhancements might be because of the impact of synthetic constituents (active compounds) of sweet basil powder, which had antimicrobial, antifungal, cancer prevention agent and mitigating impacts (Devi, 2001) and (Gurbuz and Ismael, 2016).

Feed admission was influenced by sweet basil powder in the eating regimen as appeared in the table (7) we found a straight decrease in feed utilization, yet there were no huge contrasts $(p<0.05)$ in feed utilization amid entire period (1-6 wks). This outcome concurrence with (Vahlbruch et a1., 2008) found that feed utilization was decreased directly by expanding dosages of dark seed separate amid 0 to 12 weeks of age.

Feed transformation proportion is respected a critical monetary pointer on the capacity of the flying creature to change over the eating regimen to live body weight. Critical $(\mathrm{P}<0.05)$ contrasts were seen in (Table 8$)$ in feed transformation proportion among treated and control bunches in the entire time frame.

Be that as it may, 2ndw, 3rdw and 4thw in the treated gathering of the investigation demonstrated critical enhancement $(\mathrm{P}<0.05)$ as contrasted and control gathering, individually.

These outcomes were bolstered with the discoveries of (El Gendi et al., 1994) who demonstrated that there was an enhancement in feed change with home grown items utilized as feed added substances, and could be credited to their impact on enhancing the absorbability of dietary protein in the little intestine. (Yannakopoulos, 2007) show that the basil leaves included laying hens diet enhanced the egg weight, feed proficiency and wellbeing of hens.

Toward the finish of the investigation the most astounding body weight and least FCR were identified with treated gathering, it could be proposed that to the cancer prevention agent, antifungal and sterile exercises of O.basilicum may shield the chicks proportion from oxidation and spare the estimation of nutrients and proteins of the eating regimen and furthermore it can keep the feed from the harmful impacts of mycotoxins. (Lee et al., 2005) and (Wannissorn et al., 2005). The nature of the SB could probably confer some astringency or anti-nutritional factors on the birds and thereby reduce their palatability and consumption. Similar observations were made by Nworgu et al. (2012) when growing pullets were fed diets containing graded levels of wilted water leaves.
On the other hand, antiseptic activity of this herb may reduce the numbers of harmful intestine bacteria and improve the feed absorption from gastrointestinal tract. O.basilicum is a very good source of vitamin A and unknown beneficial factors that may improve the health of the chicks as well as protecting the birds, confronted to unfavorable condition, causing an improvement in body weight and feed conversion ratio (Calucci et al., 2003).

Also, these results may be due to the high level of beta-carotene content in sweet basil, O.basilicum contain the high levels of beta-carotene and beta-cryptoxanthin which transferred to micelles after digestion (Al-Kelabi and A1-Kassie, 2013). These outcomes concur with (Lee et al., 2003) who found that some bioactive components of essential oils especially carvacrol, eugenol, improved feed conversion ratio in broiler chickens. They proposed that the effect of carvacrol, eugenol on feed conversion ratio could be related to an increase in efficiency of feed utilization.

Moreover, herbs mixture improved the utilization of feed by an increasing the activity of phosphates which acts as transferring phosphate groups from one system to another in the form of an energy-rich phosphate bond (Platel and Srinivasan, 1996).

(Cabuk et al., 2006) found better productive parameters of broilersfed supplemented by a mixture of oregano, laurel,sage, anise, and citrus essential oils. The mixture of essential oils significantly improved feed conversion ratio, which can be attributed to the more effective availability of nutrients due to the changes in the intestinal ecosystem.

\section{CONCLUSION}

Our study concluded that the additive of sweet basil has a positive effect of the $\mathrm{cGH}$ genes expression. As for body weights, it has a favorable effect during the period of first four weeks (1-4 weeks), while its effect is limited after 6 weeks old. In terms of the live body weight, the best reading of the effect of the sweet basil was recorded by calculating the total period after 6 weeks.

\section{ACKNOWLEDGMENTS}

This work was supported by the Baghdad university research council and with scientific and laboratory assistance from the University of Tehran, Faculty of veterinary medicine, Iranian National Science Foundation.

\section{ETHICAL APPROVAL}

All applicable international, national, and/or institutional 
OPEN OACCESS

guidelines for the care and use of animals were followed. All procedures performed in studies involving animals were in accordance with the ethical standards of the institution or practice at which the studies were conducted. We explained the ethical state of involving animal in our study in details in the materials and method section included the references that we were depended on.

\section{CONFLICT OF INTEREST}

This manuscript has not been previously published and is not under consideration in the same or substantially similar form in any other peer-reviewed media.

\section{AUTHORS CONTRIBUTION}

All the authors contributed to the completion of this study. The first researcher in addition to being the corresponding author, he contributed to the breeding of the study birds within the scientific conditions assigned to such studies with the provision of all the required requirements, as well as the collection of samples for the laboratory study also he was carried out the laboratory work, the second and third authors analysis of the data. The 4th author He completed the molecular study related to gene expression of growth hormone and growth hormone receptor genes, as well as the review of the manuscript as well as the suggestion of the journal of the advance in animal and veterinary science for publication of this paper.

\section{REFERENCES}

-Abraham E, Kight K, GothilfY, Du S,Zohar Y (2005).Abstracts of the 15 th ICCE $4: 24$

-Abbas Z, Colwell D, Gilleard J (2012). Botanicals: an alternative approach for the control of avian coccidiosis. Worlds Poult. Sci. J. 68: 203-215. http://dx.doi.org/10.1017/ S0043933912000268

-Al-Kelabi TJK, Al-Kassie GM (2013). Evaluation of Sweet Basil Powder Plant (Ocimumbasilicum L.) as a Feed Additives, on the Performance of broiler Chicks. Iraqi J. Vet. Med. 37:52-58.

-Alp M, Midilli M, Kocabağlı N, Yılmaz H, Turan N, Gargılı A, Acar N (2012). The effects of dietary oregano essential oil on live performance, carcass yield, serum immunoglobulin G level, and oocyst count in broilers. J. Appl. Poult. Res. 21: 630-636. https://doi.org/10.3382/japr.2012-00551

-Al-ZubaydiA (1986). Poultry management. First ed., College of Agriculture. Basrah University. (In Arabic).

- Ayssiwede SB, Zanmenou J, Issa Y, Hane M, Dieng A, Chrysostome C, Houinato M, Hornick J-L, Missohou A (2011) Nutrient composition of some unconventional and local feed resources available in Senegal and recoverable in indigenous chickens or animal feeding. Pak. J. Nutr. 10:707717. https://doi.org/10.3923/pjn.2011.707.717

- Bodeker G, Ong C-K (2005). WHO global atlas of traditional, complementary and alternative medicine. World Health
Organization.

- Cabuk M, Bozkurt M, Alcicek A, Akbap Y, Küçükyýlmaz K (2006). Effect of a herbal essential oil mixture on growth and internal organ weight of broilers from young and old breeder flocks. S. Afr. J. Anim. Sci. 36:135-141. https://doi. org/10.4314/sajas.v36i2.3996

- Calucci L, Pinzino C, Zandomeneghi M, Capocchi A, Ghiringhelli S, Saviozzi F, Tozzi S, Galleschi L (2003). Effects of $\gamma$-irradiation on the free radical and antioxidant contents in nine aromatic herbs and spices. J. Agric. Food Chem. 51:927-934. https://doi.org/10.1021/jf020739n

-Devi PU (2001). Radioprotective, anticarcinogenic and antioxidant properties of the Indian holy basil, Ocimum sanctum (Tulasi).

-E1 Gendi G, Ismail F, El Aggoury S (1994). Effect of CocciNei and Lomoton dietary supplementation as herbal growth promotors on productive performance in broilers. Ann. Agric. Sci. Moshtohor.

- Fisher T (2016). Specialty poultry production: Impact of genotype, feed strategies, alternative feedstuffs, and dietary enzymes on the growth performance and carcass characteristics of heritage breed chickens.

- Gurbuz Y, Ismael I (2016). Effect of peppermint and basil as feed additive on broiler performance and carcass characteristics. Iran. J. Appl. Anim. Sci. 6:149-156.

- Havenstein GB (2006). Performance changes in poultry and livestock following 50 years of genetic selection.

-Izmirli S, Aldavood SJ, Yasar A, Phillips CJ (2010). Introducing ethical evaluation of the use of animals in experiments in the Near East. ATLA 38:331-6

-Jameel YJ, Abed AR, Al-Shimmary FO (2014). Influence of adding garlic and thyme and their combination on immune response and some blood parameters in broiler. Sci. Agric. 2:102-106

•Kühn ER, Vleurick L, Edery M, Decuypere E, Darras VM (2002). Internalization of the chicken growth hormone receptor complex and its effect on biological functions. Comp. Biochem. Physiol., Part B: Biochem. Mol. Biol. 132:299-308 https://doi.org/10.1016/S1096-4959(02)00037-4

-Kumar O (1991). Effect of Liv-52 ${ }^{\circledR}$ syrup on broiler performance in North Eastern region. Indian Poult. Rev. 22:37-38

- Lawrence B (1988). further examination of the variation of Ocimumbasilicum L. Developments in food science

-Lee K-W, Everts H, Kappert H, Yeom K-H, Beynen A (2003). Dietary carvacrol lowers body weight gain but improves feed conversion in female broiler chickens. J. Appl. Poult. Res. 12:394-399. https://doi.org/10.1093/japr/12.4.394

-Lee S-J, Umano K, Shibamoto T, Lee K-G (2005). Identification of volatile components in basil (Ocimumbasilicum L.) and thyme leaves (Thymus vulgaris L.) and their antioxidant properties. Food Chem. 91:131-137. https://doi. org/10.1016/j.foodchem.2004.05.056

- Lin Shumao, Hongmei Li, Heping Mu, Wen Luo, Ying Li, Xinzheng Jia, Sibing Wang, Xiaolu Jia, Qinghua Nie (2012). Let- $7 \mathrm{~b}$ regulates the expression of the growth hormone receptor gene in deletion-type dwarf chickens. BMC Genomics. 13: 306. https://doi.org/10.1186/1471-2164-13306

- Mohamed AB, Huseen FA, Jawad OT (2011). Effect of cinnamon (Cinnamomumzylenicum) supplementation on the intestinal selected bacterial population in Japanese quail. Roavs. 1(5): 276-278.

- National Research Council (US) Committee to Review 
(1994). Building consensus through risk assessment and management of the Department of Energy's environmental remediation program. DOE Assistant Secretary for Environmental Restoration and Waste Management.

- Nweze O, Ekwe O (2012). Growth performance, gut and haemo-microbial study of finishing broilers fed African sweet basil (Ocimumgratissimum) leaf extract. Ozean J. Appl. Sci. 5(2),185-191

- Nworgu C, Oduola A, Falola O, Adeboye K, Olajide O, Akingbogun O, Oguntayo T (2012). Effect of wilted water leaf (Talinum triangulare) leaves on the performance of growing pullets. Proceedings of the 37th Nigerian Societ. Anim. Prod. (pp. 312-315).

- Özcan M, CHALCHAT J-C (2002). Essential Oil Composition of Ocimumbasilicum L. Czech J. Food Sci. 20: 223-228. https://doi.org/10.1080/10412905.2002.9699875

-Parati K, Bongioni G, Aleandri R, Galli A (2006). Sex ratio determination in bovine semen: A new approach by quantitative real time PCR. Theriogenology. 66: 2202-2209 https://doi.org/10.1016/j.theriogenology.2006.07.007.

-Pfaffl MW (2001). A new mathematical model for relative quantification in real-time RT-PCR. Nucleic. Acids Res. 29:e45-e45. https://doi.org/10.1093/nar/29.9.e45

-Platel K, Srinivasan K (1996). Influence of dietary spices or their active principles on digestive enzymes of small intestinal mucosa in rats. Int. J. Food Sci. Nutr. 47: 55-59. https://doi. org/10.3109/09637489609028561
- Pierce AL, Fukada H, Dickhoff WW (2005). Metabolic hormones modulate the effect of growth hormone $(\mathrm{GH})$ on insulin-like growth factor-I (IGF-I) mRNA level in primary culture of salmon hepatocytes. J. Endocrinol. 184(2): 341349. https://doi.org/10.1677/joe.1.05892

- Rabia A (2010). Effect of using fengugreek, parsley and sweet basil seeds as feed additive on the performance of broiler chickens. Inter. J. Poult. Sci. 9(3): 278-282. https://doi. org/10.3923/ijps.2010.278.282

-Vahlbruch H, Mehmet M, Chelkowski S, Hage B, Franzen A, Lastzka N, Goßler S, Danzmann K, Schnabel R (2008). Observation of squeezed light with $10-\mathrm{dB}$ quantumnoise reduction. Phys. Rev. Lett. 100: 033602. https://doi. org/10.1103/PhysRevLett.100.033602

-Wannissorn B, Jarikasem S, Siriwangchai T, Thubthimthed S (2005). Antibacterial properties of essential oils from Thai medicinal plants. Fitoterapia. 76: 233-236. https://doi. org/10.1016/j.fitote.2004.12.009

-Yannakopoulos A (2007). Egg enrichment in omega-3 fatty acids. Bioactive egg compounds. Springer. https://doi. org/10.1007/978-3-540-37885-3_20

-Zhao R, Muehlbauer E, Decuypere E, Grossmann R (2004). Effect of genotype-nutrition interaction on growth and somatotropic gene expression in the chicken. Gen. Comp. Endocrinol. 136:2-11. https://doi.org/10.1016/j. ygcen.2003.11.009 